\section{Early Flurprimidol Drench Applications Suppress Final Height of Four Poinsettia Cultivars}

\author{
Christopher J. Currey and Roberto G. Lopez ${ }^{1}$
}

ADDITIONAL INDEX WORDs. chlormequat chloride, daminozide, plant growth retardant, stem elongation, tank mix, Topflor

Summary. Plant growth retardants (PGRs) are commonly applied to control poinsettia (Euphorbia pulcherrima) stem elongation to meet a target final height. Two weeks after pinching, $4-\mathrm{fl} \cdot \mathrm{oz}$ substrate drenches containing $0.0,0.05,0.10$, $0.15,0.20$, or $0.25 \mathrm{mg} \cdot \mathrm{L}^{-1}$ flurprimidol were applied to high-vigor 'Orion' and low-vigor 'Polly Pink' poinsettia (Expt. I); while drenches containing 0.0, 0.05, 0.10 , or $0.15 \mathrm{mg} \cdot \mathrm{L}^{-1}$ flurprimidol or a foliar spray containing $1250 \mathrm{mg} \cdot \mathrm{L}^{-1}$ daminozide and $750 \mathrm{mg} \cdot \mathrm{L}^{-1}$ chlormequat chloride were applied to high-vigor 'Classic Red' and low-vigor 'Freedom Salmon' poinsettia (Expt. II). Final height of 'Orion' and 'Polly's Pink' poinsettia was suppressed by $12 \%$ to $25 \%$ and $13 \%$ to $30 \%$, respectively, as flurprimidol concentration increased from 0.05 to 0.25 $\mathrm{mg} \cdot \mathrm{L}^{-1}$. Final height of 'Classic Red' and 'Freedom Salmon' was suppressed by $11 \%$ to $30 \%$ and $10 \%$ to $19 \%$, respectively, as flurprimidol concentration increased from 0.05 to $0.15 \mathrm{mg} \cdot \mathrm{L}^{-1}$. Although the daminozide and chlormequat chloride spray had no significant effect on bract area index compared with untreated plants, bract area index was smaller for all plants treated with flurprimidol. However, the bract area to height ratio of all cultivars was not impacted by any PGR application, indicating aesthetic appearance was not negatively affected with smaller bract area. Time to anthesis was delayed by up to 4 days when $0.10 \mathrm{mg} \cdot \mathrm{L}^{-1}$ was applied to 'Classic Red', although no significant delays were observed for the remaining cultivars. Based on these results, flurprimidol may be applied as an early drench to suppress height of poinsettia without adversely impacting finished plant quality or crop timing.

$\mathrm{P}$ oinsettia is an important flowering potted crop in the United States with a wholesale value of over \$153 million (U.S. Department of Agriculture, 2009). Poinsettia height can exceed the requirements for commercially acceptable finished plants, and stem elongation frequently requires suppression to produce a marketable plant with a final height of 14 to 16 inches (Fisher and Heins, 1995). To ensure that plants finish within a specific height range, producers may employ a graphical tracking program that has a minimum and

Department of Horticulture and Landscape Architecture, Purdue University, West Lafayette, IN 47907 2010

We gratefully acknowledge Diane Camberato, Rob Eddy, and Dan Hahn for greenhouse assistance, funding from growers providing support for Purdue University floriculture research, and support from the Purdue Agricultural Experiment Station. We thank Paul Ecke Ranch and Syngenta Flowers for plant material, Conrad Fafard for growing media, SePRO for chemicals and funding, Fine Americas for chemicals, Greencare for fertilizer, and ITML for pots.

The use of trade names in this publication does not imply endorsement by Purdue University of products named nor criticism of similar ones not mentioned.

${ }^{1}$ Corresponding author. E-mail: rglopez@purdue.edu. maximum target height range based on the cultivar response time, height at pinching, and final desired height (Fisher and Heins, 2002). Actual plant height of a subset of the population is measured weekly and plotted on the graph. As plant height exceeds the maximum target height curve, growers must implement strategies to control stem elongation.

There are numerous genetic, environmental, and cultural strategies available to produce compact and marketable poinsettia (Berghage and Heins, 1991; Ecke et al., 2004; Hammer and Barrett, 2001; Liu and Heins, 2002). Final height can be controlled genetically by selecting cultivars that flower early or have short internodes (Ecke et al., 2004). Stem elongation can be controlled environmentally by reducing the difference between the day and night air temperatures (Berghage and Heins, 1991). Additionally, increasing plant spacing and/or the daily light integral can suppress plant height (Liu and Heins, 2002). However, the most common cultural method of controlling poinsettia height is the application of PGRs (Hammer and Barrett, 2001).

Compared with foliar sprays, PGRs applied as substrate drenches provide more uniform control over a longer duration (Boldt, 2008; Ecke et al., 2004; Gent and McAvoy, 2000). Applying PGRs to the substrate has been reported to be effective in controlling poinsettia stem elongation (Barrett and Nell, 1982; Barrett et al., 1994; Faust et al., 2001; Newman and Tant, 1995; Niu et al., 2002; Wilfret, $1978,1993,1996)$. Though substrate drenches are commonly used to control late-season stretch (Cox, 2000; Faust and Klein 1998; Moore, 1996), applying drenches containing paclobutrazol or uniconazole early in the production cycle is an emerging PGR application strategy for height control (Barrett, 2004; Dole and Wilkins, 2005; Lopez and Runkle, 2007).

Flurprimidol is a relatively new PGR in the U.S. marketplace that is similar to paclobutrazol and uniconazole in both chemical structure and mode of action and is effective when applied as a substrate drench (Krug et al., 2005a, b, 2006). Though we have found one report of using flurprimidol as a drench on poinsettia (McDaniel, 1986), the research was performed using a different formulation of the chemical with cultivars no longer in commercial cultivation. Our objective in this study was to identify the impact of early flurprimidol drench applications on stem elongation of modern highand low-vigor poinsettia cultivars.

\begin{tabular}{lllc}
\hline $\begin{array}{l}\text { Units } \\
\text { To convert U.S. to SI, } \\
\text { multiply by }\end{array}$ & U.S. unit & SI unit & $\begin{array}{l}\text { To convert SI to U.S., } \\
\text { multiply by }\end{array}$ \\
\hline 29.5735 & fl oz & $\mathrm{mL}$ & 0.0338 \\
2.54 & inch $(\mathrm{es})$ & $\mathrm{cm}$ & 0.3937 \\
6.4516 & inch $^{2}$ & $\mathrm{~cm}^{2}$ & 0.1550 \\
16.3871 & inch $^{3}$ & $\mathrm{~cm}^{3}$ & 0.0610 \\
28,350 & $\mathrm{oz}$ & $\mathrm{Mg}$ & $3.5274 \times 10^{-5}$ \\
1 & $\mathrm{ppm}$ & $\mathrm{mg} \cdot \mathrm{L}^{-1}$ & 1 \\
0.001 & $\mathrm{ppm}$ & $\mathrm{mL} \cdot \mathrm{L}^{-1}$ & 1000 \\
$\left({ }^{\circ} \mathrm{F}-32\right) \div 1.8$ & ${ }^{\circ} \mathrm{F}$ & ${ }^{\circ} \mathrm{C}$ & $\left(1.8 \times{ }^{\circ} \mathrm{C}\right)+32$ \\
& & &
\end{tabular}




\section{Materials and methods}

EXPERIMENT I. On 2 and 17 Aug. 2009 , single-rooted cuttings of highvigor 'Orion' and low-vigor 'Polly's Pink' poinsettia, respectively, were planted in 6.5-inch-diameter round plastic containers ( 103.7 inch $^{3}$ volume) containing soil-less substrate comprising (v/v) 80\% sphagnum peat and 20\% perlite (Fafard IP; Conrad Fafard, Agawam, MA). Plants were pinched to six nodes $14 \mathrm{~d}$ after planting. A 4 -fl.oz substrate drench of solutions containing deionized water and $0,0.05,0.10$, $0.15,0.20$, or $0.25 \mathrm{mg} \cdot \mathrm{L}^{-1}$ flurprimidol (Topflor; SePRO, Carmel, IN) was applied to substrate surfaces $14 \mathrm{~d}$ after pinching when shoots were $\approx 1$ inch long.

Plants were irrigated as necessary with acidified water supplemented with water-soluble fertilizer (15N-1.3P2.5K; Greencare Fertilizers, Kankakee, IL) to provide the following at each irrigation (in $\mathrm{mg} \cdot \mathrm{L}^{-1}$ ): $200 \mathrm{~N}, 17 \mathrm{P}$, $176 \mathrm{~K}, 40 \mathrm{Ca}, 27 \mathrm{Mg}, 1.0 \mathrm{Fe}, 0.5 \mathrm{Mn}$ and $\mathrm{Zn}, 0.24 \mathrm{Cu}$ and $\mathrm{B}$, and 0.1 Mo. Irrigation water was supplemented with $93 \%$ sulfuric acid (Ulrich Chemical, Indianapolis, IN) at $0.08 \mathrm{~mL} \cdot \mathrm{L}^{-1}$ to reduce alkalinity to $100 \mathrm{mg} \cdot \mathrm{L}^{-1}$ and $\mathrm{pH}$ to a range of 5.7 to 6.0 .

Plants were grown in a polyethylenecovered greenhouse with exhaust fan and evaporative cooling pad and radiant hot water heating controlled by an environmental computer (EnviroSTEP; Wadsworth Control Systems, Arvada, $\mathrm{CO})$. The greenhouse day and night temperature set points were $24 \pm 1$ and $19 \pm 1{ }^{\circ} \mathrm{C}$, respectively. Plants were grown under ambient light with dayextension lighting. An oscillating highpressure sodium lamp (Beamflicker; Parsource, Petaluma, CA) delivered a supplemental photosynthetic photon flux $(P P F)$ varying between 3 and $59 \mu \mathrm{mol} \cdot \mathrm{m}^{-2} \cdot \mathrm{s}^{-1}$ at plant height [as measured with a quantum sensor (LICOR Biosciences, Lincoln, NE)] from 1700 to 2200 HR (Blanchard and Runkle, 2009). On 1 and 15 Oct., inductive short day (SD) photoperiods were initiated for 'Orion' and 'Polly's Pink', respectively. Short days were achieved by covering the plants with an opaque cloth at $1600 \mathrm{HR}$ and retracting the cloth at $0800 \mathrm{HR}$. Environmental data are reported in Table 1.

Plant height was measured weekly and plotted in a graphical tracking program (Fig. IA and B) (Fisher and
Heins, 2002). At visible anthesis (first pollen shed) of two branches, the date, plant height from the base of the pot to the top of the apical meristem, and bract length and width of the two flowering stems (widest diameter and diameter $90^{\circ}$ across) were recorded. Bract area index of each of the flowering stems was determined by using the formula for an ellipse [(widest diameter $\times$ shortest diameter $\times \pi) /(4)]$

Table 1. Average daily greenhouse air temperature (ADT) and daily light integral (DLI) during each month for 'Orion' and 'Polly's Pink' poinsettia treated with flurprimidol drenches (Expt. I) and for 'Classic Red' and 'Freedom Salmon' poinsettia treated with flurprimidol drenches or a daminozide and chlormequat chloride foliar spray (Expt. II).

\begin{tabular}{lccccc}
\hline & \multicolumn{2}{c}{ Expt. I } & & \multicolumn{2}{c}{ Expt. II } \\
\cline { 2 - 3 } Mo. & $\begin{array}{c}\text { ADT [mean } \pm \\
\left.\text { SD }\left({ }^{\circ} \mathbf{C}\right)\right]^{\mathbf{z}}\end{array}$ & $\begin{array}{c}\text { DLI } \\
\left(\mathbf{m o l} \cdot \mathbf{m}^{-2} \cdot \mathbf{d}^{-\mathbf{1}}\right)\end{array}$ & $\begin{array}{c}\text { ADT [mean } \pm \\
\left.\text { SD }\left({ }^{\circ} \mathbf{C}\right)\right]\end{array}$ & $\begin{array}{c}\text { DLI } \\
\left(\mathbf{m o l}^{-2} \mathbf{m}^{-2} \cdot \mathbf{d}^{-\mathbf{1}}\right)\end{array}$ \\
\hline August & $23.1 \pm 2.9$ & 18.5 & & $22.7 \pm 1.7$ & 15.5 \\
September & $21.8 \pm 2.1$ & 19.0 & & $22.5 \pm 2.1$ & 14.5 \\
October & $21.3 \pm 2.5$ & 9.5 & & $21.2 \pm 2.6$ & 6.6 \\
November & $21.7 \pm 2.2$ & 9.6 & & $21.9 \pm 2.4$ & 8.5 \\
December & $20.9 \pm 2.0$ & 8.5 & & $20.9 \pm 2.1$ & 3.9 \\
\hline
\end{tabular}

${ }^{z}\left(1.8 \times{ }^{\circ} \mathrm{C}\right)+32={ }^{\circ} \mathrm{F}$

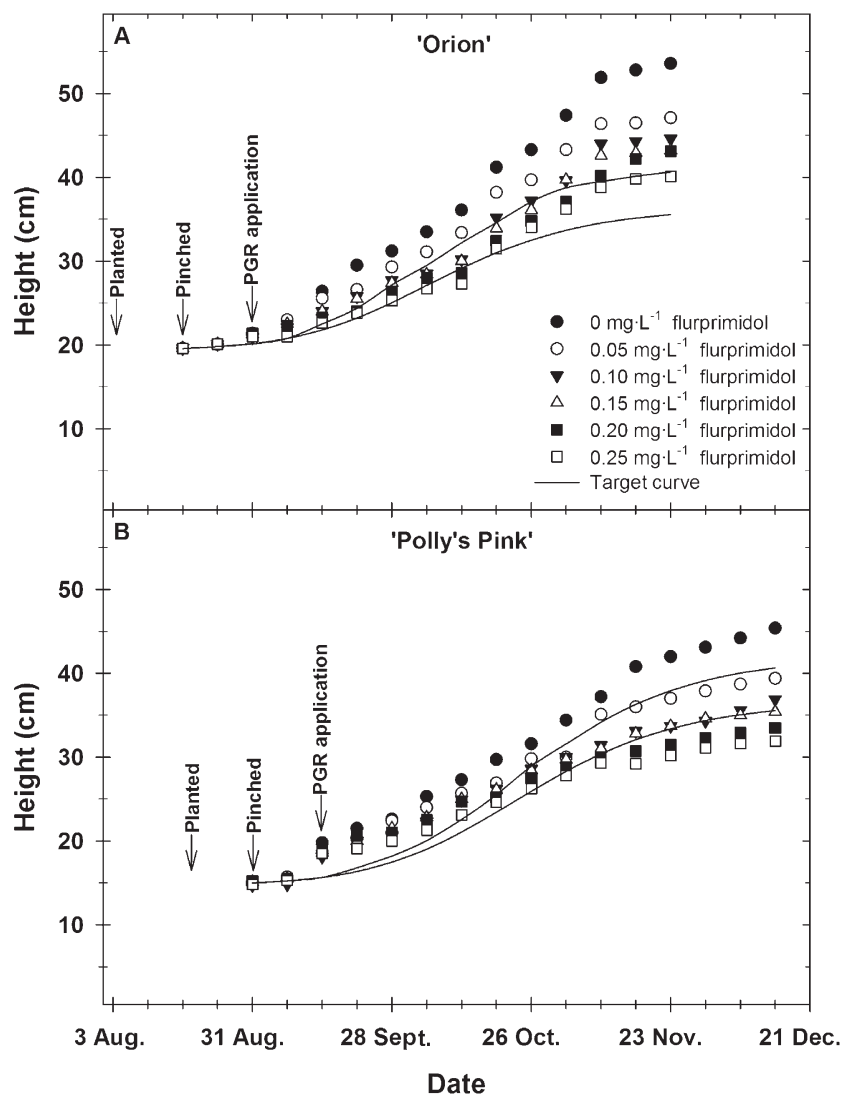

Fig. 1. Graphical tracking chart displaying the minimum and maximum target heights (solid lines) and weekly average heights of 'Orion' (A) and 'Polly's Pink' (B) poinsettia treated with plant growth retardant (PGR) drenches containing flurprimidol 2 weeks after pinching; $1 \mathrm{~cm}=0.3937 \mathrm{inch}, 1 \mathrm{mg} \cdot \mathrm{L}^{-1}=1 \mathrm{ppm}$. 
per treatment per cultivar. Data were analyzed using SPSS (version 17.0; SPSS, Chicago, IL).

EXPERIMENT II. On 2 and 17 Aug. 2009, high-vigor 'Classic Red' and low-vigor 'Freedom Salmon' poinsettia, respectively, were planted and pinched as outlined in Expt. I. A 4-fl.oz substrate drench of solutions containing deionized water and $0,0.05,0.10$, or $0.15 \mathrm{mg} \cdot \mathrm{L}^{-1}$ flurprimidol (Topflor) or a commercially standard foliar spray containing $1250 \mathrm{mg} \cdot \mathrm{L}^{-1}$ daminozide (Dazide; Fine Americas, Walnut Creek, $\mathrm{CA}$ ) and $750 \mathrm{mg} \cdot \mathrm{L}^{-1}$ chlormequat chloride (Citadel, Fine Americas) were applied $14 \mathrm{~d}$ after pinching. 'Classic Red' was treated again $35 \mathrm{~d}$ after pinching because plant height was exceeding the graphical tracking curve (Fig. 2A).

Plants were irrigated and fertilized as outlined in Expt. I. The plants were grown in a glass-glazed greenhouse with exhaust fan and pad evaporative cooling and radiant hot water heating controlled by an environmental computer (Maximizer Precision 10; Priva Computers, Vineland Station, ON, Canada). The greenhouse day and night temperature set points were $24 \pm 1$ and $19 \pm 1{ }^{\circ} \mathrm{C}$, respectively. A 16-h photoperiod (0600 to $2200 \mathrm{HR}$ ) was maintained, consisting of natural daylengths with day-extension lighting. Highpressure sodium lamps delivered a supplemental $P P F$ of $100 \mu \mathrm{mol} \cdot \mathrm{m}^{-2} \cdot \mathrm{s}^{-1}$ at plant height [as measured with a quantum sensor (LI-COR Biosciences)] from 1700 to $2200 \mathrm{Hr}$. On 1 and 15 Oct., SD were initiated for 'Classic Red' and 'Freedom Salmon', respectively, as outline in Expt. I. Environmental data are reported in Table 1 .

Data collection was as outlined in Expt. I. Analyses of variance were performed on data and pairwise comparisons between treatments were performed using Tukey's honestly significant difference test at $P \leq$ 0.05 using SPSS (version 17.0).

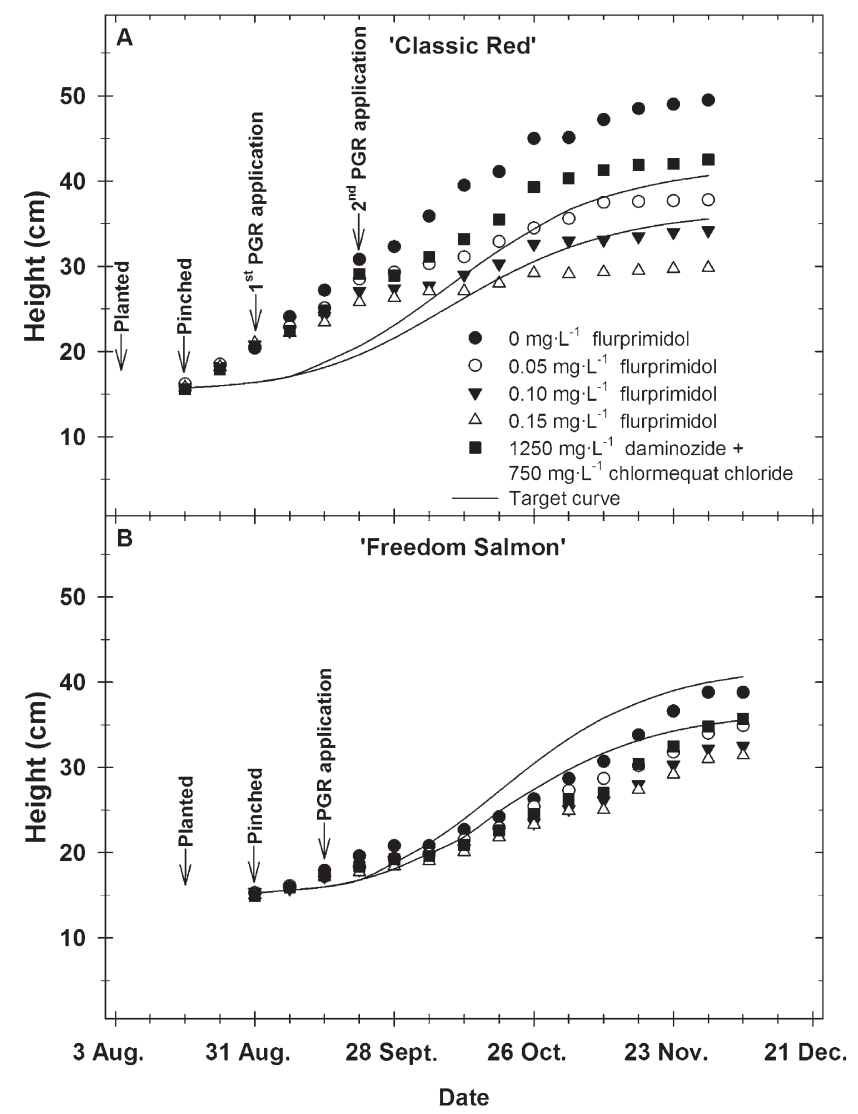

Fig. 2. Graphical tracking chart displaying the minimum and maximum target heights (solid lines) and weekly average heights of 'Classic Red' (A) and 'Freedom Salmon' (B) poinsettia treated with plant growth retardant (PGR) drenches containing flurprimidol or sprays with a solution containing daminozide and chlormequat chloride 2 weeks after pinching. 'Classic Red' was treated again 5 weeks after pinching; $1 \mathrm{~cm}=0.3937 \mathrm{inch}, 1 \mathrm{mg} \cdot \mathrm{L}^{-1}=1 \mathrm{ppm}$.

\section{Results \\ Experiment I}

'Orion'. Final height of 'Orion' was 6.5 to $13.5 \mathrm{~cm}$ shorter than untreated plants as flurprimidol concentration increased from 0.05 to 0.25 $\mathrm{mg} \cdot \mathrm{L}^{-1}$, respectively (Fig. 3A). Applying $0.25 \mathrm{mg} \cdot \mathrm{L}^{-1}$ flurprimidol produced plants that were $40.1 \mathrm{~cm}$ tall, which was within the target range for finished plant height. Though bract area index decreased from 1240 to $891 \mathrm{~cm}^{2}$ as flurprimidol concentration increased from 0.05 to $0.20 \mathrm{mg} \cdot \mathrm{L}^{-1}$, respectively, bract area index of plants treated with $0.25 \mathrm{mg} \cdot \mathrm{L}^{-1}$ was $1068 \mathrm{~cm}^{2}$, compared with $1325 \mathrm{~cm}^{2}$ for untreated plants (Fig. 3B). The ratio of bract area to height and time to anthesis were unaffected by flurprimidol treatments (Fig. 3C and D).

'Polly's Pink'. Final plant height for plants treated with 0.05 to $0.25 \mathrm{mg} \cdot \mathrm{L}^{-1}$ drenches were 6 to 13.5 $\mathrm{cm}$ shorter than untreated plants (Fig. $3 \mathrm{~A})$. When 0.05 or $0.10 \mathrm{mg} \cdot \mathrm{L}^{-1}$ flurprimidol drenches were applied, plants were 39.4 or $36.9 \mathrm{~cm}$ tall, respectively, which met desired plant height. Untreated plants had a bract area of 956 $\mathrm{cm}^{2}$. Flurprimidol drenches at low concentrations did not have a substantive effect on bract area index, though plants treated with 0.20 or $0.25 \mathrm{mg} \cdot \mathrm{L}^{-1}$ flurprimidol had bract area indices of 858 or $734 \mathrm{~cm}^{2}$, respectively (Fig. 3B). The bract area to height ratio increased with flurprimidol treatments up to $0.15 \mathrm{mg} \cdot \mathrm{L}^{-1}$ (Fig. 3C). Flurprimidol drenches had little effect on the time to anthesis $\left(R^{2}=0.16\right)$ (Fig. 3D).

\section{Experiment II}

'Classic Red'. All PGR treatments suppressed final height compared with untreated plants (Fig. 4A). Increasing flurprimidol concentrations from 0.05 to $0.15 \mathrm{mg} \cdot \mathrm{L}^{-1}$ produced plants that were 11.7 to $19.7 \mathrm{~cm}$ shorter, respectively, than untreated plants, while the foliar sprays suppressed final height by $7 \mathrm{~cm}$ (Fig. 4A). Plants treated with the foliar sprays or $0.05 \mathrm{mg} \cdot \mathrm{L}^{-1}$ flurprimidol drenches met the target height. Untreated plants had a bract area index of $1244 \mathrm{~cm}^{2}$ (Fig. 4B). While foliar sprays did not reduce bract area index, drenches with 0.05 to $0.15 \mathrm{mg} \cdot \mathrm{L}^{-1}$ resulted in plants with smaller bract area indices of 854 to $637 \mathrm{~cm}^{2}$, respectively (Fig. 4B). The bract area to height ratio was unaffected by 


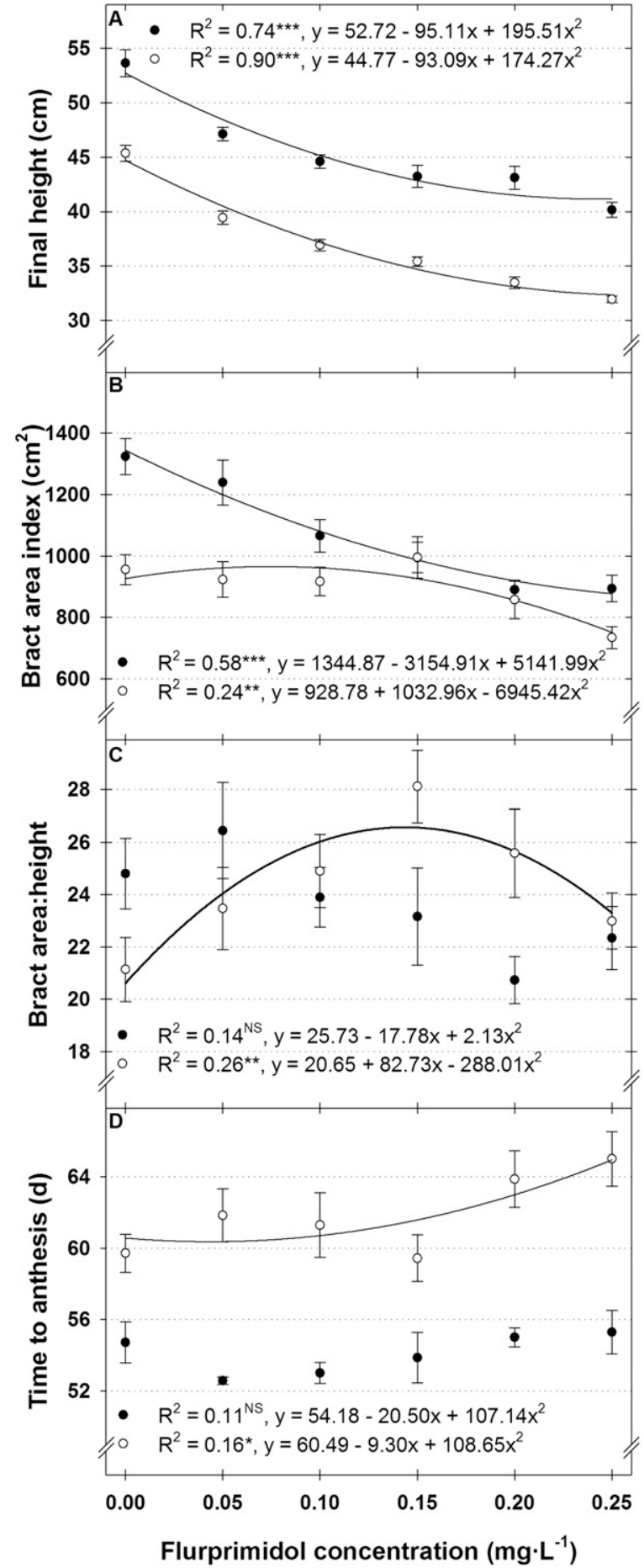

Fig. 3. Final height (A), bract area index (B), bract area/height ratio (C), and time to anthesis (D) of 'Orion' (closed circles) and 'Polly's Pink' (open circles) poinsettia treated with substrate drenches containing flurprimidol 2 weeks after pinching. Bract area index of each of the flowering stems was determined by using the formula for an ellipse [(widest diameter $\times$ shortest diameter $\times \pi) /(4)]$ and averaged. Regression lines are presented for significant correlations only. NS, *, **, *** indicates not significant or significant at $P \leq 0.05,0.1$, or 0.001 , respectively; $1 \mathrm{~cm}=0.3937$ inch, $1 \mathrm{~cm}^{2}=0.1550$ inch $^{2}, 1 \mathrm{mg} \cdot \mathrm{L}^{-1}=1 \mathrm{ppm}$.

any PGR treatment (Fig. 4C). Time to anthesis was unaffected by 0.05 and 0.15 ppm flurprimidol drenches and the daminozide and chlormequat chloride spray, though applying 0.10 $\mathrm{mg} \cdot \mathrm{L}^{-1}$ flurprimidol delayed anthesis by $4 \mathrm{~d}$ compared with untreated plants (Fig. 4D).
'Freedom Salmon'. Final height of untreated plants was $38.8 \mathrm{~cm}$ (Fig. $4 \mathrm{~A}$ ). The daminozide and chlormequat foliar spray did not affect final height; however, as flurprimidol concentration increased from 0.05 to $0.15 \mathrm{mg} \cdot \mathrm{L}^{-1}$, plants were 3.9 to $7.4 \mathrm{~cm}$ shorter, respectively, than untreated plants (Fig. 4A). Only untreated plants and plants sprayed with the daminozide and chlormequat met the target height. Untreated plants had a bract area index of $825 \mathrm{~cm}^{2}$ (Fig. 4B). Compared with untreated plants, the daminozide and chlormequat chloride spray did not produce plants with significantly smaller bract area indices (Fig. 4B). Increasing flurprimidol concentrations from 0.05 to 0.15 $\mathrm{mg} \cdot \mathrm{L}^{-1}$ produced plants with smaller bract area indices ranging from 676 to $622 \mathrm{~cm}^{2}$, respectively (Fig. 4B). There were no differences among the bract area to height ratio or time to anthesis of plants treated with PGRs compared with untreated plants (Fig. 4C and D).

\section{Discussion}

We have demonstrated that flurprimidol can be used effectively as an early drench to control final poinsettia height in the northern United States. However, we observed differences among high- and low-vigor cultivars regarding the need for height control. For example, 'Classic Red', a vigorous cultivar, required an additional PGR drench when compared with 'Freedom Salmon', a lower-vigor cultivar. With the use of graphical tracking, we observed that the height of 'Classic Red' exceeded the upper limit of the graphical tracking curve after the first PGR application, thus requiring a second application. Alternatively, 'Freedom Salmon' did not require any PGR as final height of untreated plants was between the 14- and 16-inch final target height. This demonstrates the difficulty in applying a preventative height control measure such as early drenches. We were able to achieve comparable height control as reported by McDaniel (1986), yet with about one-half the amount of a.i. applied per container. This may be attributed to differences in the latitudes of study locations $\left(\approx 5^{\circ}\right)$, poinsettia cultivars used, and/or chemical formulation between the studies.

For all cultivars used in this study, we observed smaller bract area indexes for plants treated with flurprimidol 


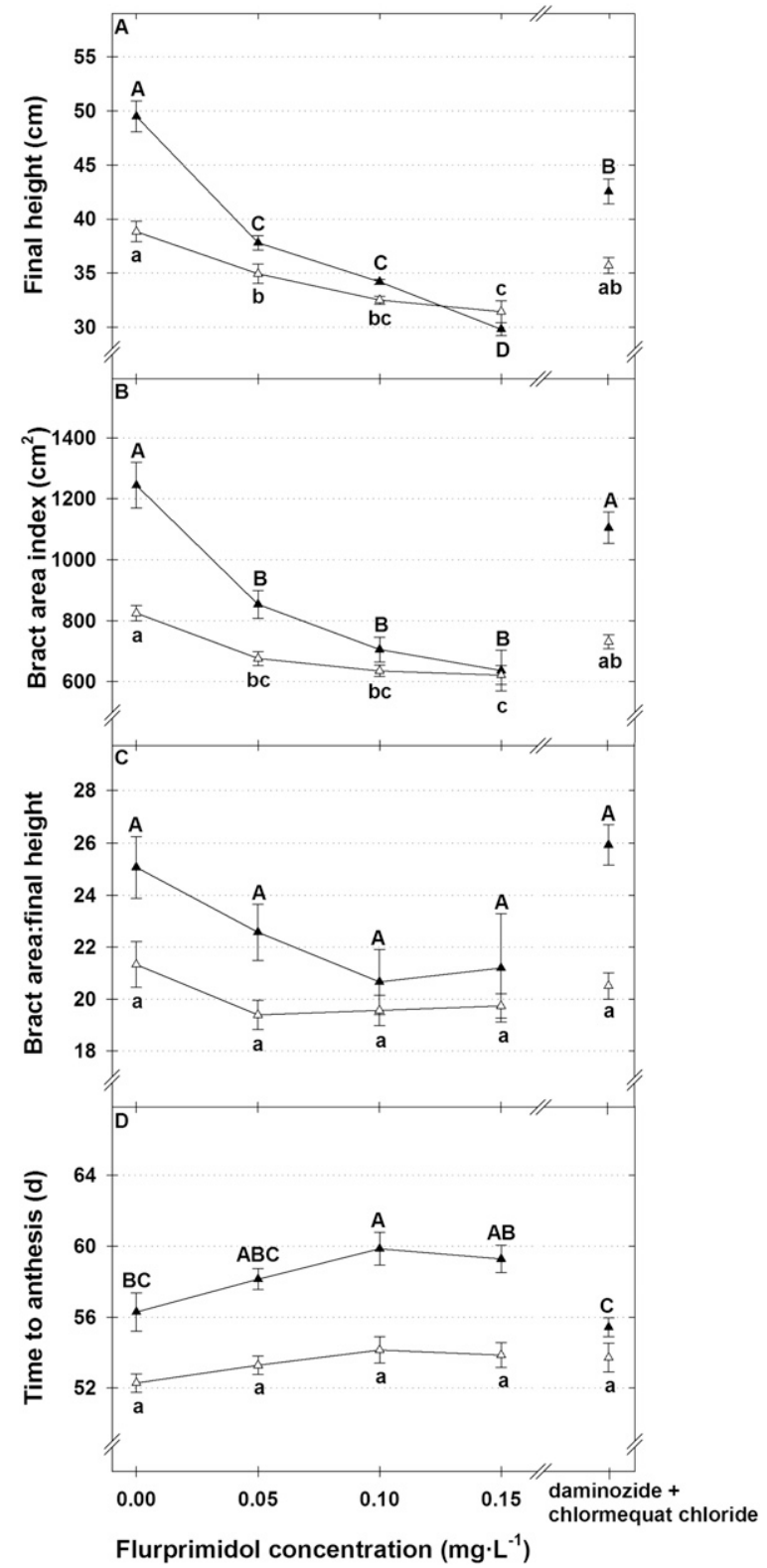

Fig. 4. Final height (A), bract area index (B), bract area/height ratio (C), and time to anthesis (D) of 'Classic Red' (closed triangles) and 'Freedom Salmon' (open triangles) poinsettia treated with substrate drenches containing flurprimidol or sprayed with a solution containing $1250 \mathrm{mg} \cdot \mathrm{L}^{-1}$ daminozide and $750 \mathrm{mg} \cdot \mathrm{L}^{-1}$ chlormequat chloride 2 weeks after pinching. 'Classic Red' was treated again 5 weeks after pinching. Bract area index of each of the flowering stems was determined by using the formula for an ellipse [(widest diameter $\times$ shortest diameter $\times \pi) /(4)$ ] and averaged. Different upper- or lowercase letters are significantly different by Tukey's honestly significant difference test at $P \leq 0.05$ within 'Classic Red' or 'Freedom Salmon', respectively; $1 \mathrm{~cm}=0.3937 \mathrm{inch}, 1 \mathrm{~cm}^{2}=0.1550$ inch $^{2}$, $1 \mathrm{mg} \cdot \mathrm{L}^{-1}=1 \mathrm{ppm}$.

drenches compared with untreated plants. This negative impact on bract development may be attributed to the pattern of flurprimidol release in the substrate. When applied to the substrate, paclobutrazol binds to organic media components and releases over several weeks (Boldt, 2008). We hypothesize that flurprimidol might have measure of bract area per se, the smaller flower diameters would seem to indicate smaller bract area as well.

Though bract area indices for all cultivars used were smaller as a result of flurprimidol drenches, we observed little, if any, negative effect on the ratio of bract area to height for all cultivars. Furthermore, 'Polly's Pink' poinsettia treated with flurprimidol generally had a greater bract area index relative to plant height compared with untreated plants. Though McDaniel (1986) did not report a bract area to height ratio, a ratio similar to bract area/height may be created when flower diameter is divided by final plant height. The flower diameter/height ratio for flurprimidoltreated 'Eckespoint C-1 Red' did not change compared with untreated plants, while flurprimidol-treated 'Annette Hegg Dark Red' and 'Gutbier V-14 Glory' had larger flower diameter/ height ratios compared with untreated plants (McDaniel, 1986). Although bract area is smaller when plants are treated with early flurprimidol drenches, the smaller bract area and suppressed plant height are proportional to each other. Therefore, the smaller bract area does not negatively impact the aesthetic quality of finished plants treated with early flurprimidol drenches.

The effect of early flurprimidol drenches on days to anthesis varied with cultivar. Flowering of 'Freedom Salmon' was not delayed when treated with Topflor. After two flurprimidol treatments, flowering was delayed by up to $4 \mathrm{~d}$ in 'Classic Red'. Delays of up to 4.5 to $5.5 \mathrm{~d}$ were reported when $0.12 \mathrm{mg} /$ pot flurprimidol was applied to 'Eckespoint C-1 Red', 'Annette Hegg Dark Red', and 'Gutbier V-14 Glory' (McDaniel, 1986). These delays may not be commercially significant as final height was measured at first pollen shed when bracts would have been nearly fully developed and already at the marketable stage.

\section{Conclusions}

The results presented here are in agreement with previous research and provide new insight into early flurprimidol drenches applied to poinsettia grown in the northern United States. It is clear that flurprimidol drenches are effective in suppressing final height without adversely impacting time to anthesis or aesthetic quality. Producers may want to conduct on-site trials as to determine the appropriate 
concentration of a.i. for their location, production schedule, and poinsettia cultivars used.

\section{Literature cited}

Barrett, J. 2004. Poinsettias: Early PGR drench? Greenhouse Product News 14(8): 42-48.

Barrett, J.E., C.A. Bartuska, and T.A. Nell. 1994. Comparison of paclobutrazol drench and spike applications for height control of potted floriculture crops. HortTechnology 29:180-182.

Barrett, J.E. and T.A. Nell. 1982. Irrigation interval and growth retardants affect poinsettia development. Proc. Florida State Hort. Soc. 95:167-169.

Berghage, R.D. and R.D. Heins. 1991. Quantification of temperature effects on stem elongation in poinsettia. J. Amer. Soc. Hort. Sci. 116:14-18.

Blanchard, M.G. and E.S. Runkle. 2009. Use of a cyclic high-pressure sodium lamp to inhibit flowering of chrysanthemum and velvet sage. Sci. Hort. 122:448-454.

Boldt, J.L. 2008. Whole plant response of chrysanthemum to paclobutrazol, chlormequat chloride, and (s)-abscisic acid as a function of exposure time using a split-root system. Univ. Florida, Gainesville, MS Thesis.

Cox, D. 2000. Late season application of paclobutrazol to control stretch of poinsettia. Southeastern Floriculture 10(5):18-20.

Dole, J.M. and H.F. Wilkins. 2005. Floriculture: Principles and species. Prentice Hall, Upper Saddle River, NJ.

Ecke, P., III, J.E. Faust, J. Wiggins, and A. Higgins. 2004. Height control, p. 51-72. In: The Ecke poinsettia manual. Ball Publishing, Batavia, IL.
Faust, J.E. and R. Klein. 1998. The five factors that contribute to late-season stretch in poinsettias and how to apply growth regulators to compensate for them. Greenhouse Product News 8(10): 19-22.

Faust, J.E., P.C. Korczynski, and R. Klein. 2001. Effects of paclobutrazol drench application date on poinsettia height and flowering. HortTechnology 11:557-560.

Fisher, P.R. and R.D. Heins. 1995. A process-control approach to poinsettia height control. HortTechnology 5:57-63.

Fisher, P.R. and R.D. Heins. 2002. UNH FloraTrack for poinsettia: Graphical tracking plant height on computer. Univ. New Hampshire Coop. Ext., Durham, NC.

Gent, M.P.N. and R.J. McAvoy. 2000. Plant growth retardants in ornamental horticulture, p. 89-146. In: A.S. Basara (ed.). Plant growth regulators in agriculture and horticulture: Their role and commercial uses. Food Products Press, Binghamton, NY.

Hammer, A. and J. Barrett. 2001. Poinsettias, p. 111-116. In: M.L. Gaston, P.S. Konjoian, L.A. Kunkle and M.F. Wilt (eds.). Tips on regulating growth of floriculture crops. Ohio Florists' Assn. Services, Columbus, $\mathrm{OH}$.

Krug, B.A., B.E. Whipker, and I. McCall. 2005a. Flurprimidol is effective at controlling height of 'Star Gazer' oriental lily. HortTechnology 15:373-376.

Krug, B.A., B.E. Whipker, I. McCall, and J.M. Dole. 2005b. Comparison of flurprimidol to ancymidol, paclobutrazol, and uniconazole for tulip height control. HortTechnology 15:371-373.

Krug, B.A., B.E. Whipker, I. McCall, and J.M. Dole. 2006. Narcissus response to plant growth regulators. HortTechnology 16:129-132.

Liu, B. and R.D. Heins. 2002. Photothermal ratio affects plant quality in 'Freedom' poinsettia. J. Amer. Soc. Hort. Sci. 127:2026.

Lopez, R. and E. Runkle. 2007. Early PGR drench applications on poinsettia. Greenhouse Product News 17(8):22-29.

McDaniel, G.L. 1986. Comparison of paclobutrazol, flurprimidol, and tetcyclacis for controlling poinsettia height. HortScience 21:1161-1163.

Moore, S.R. 1996. Late growth regulator tips. GrowerTalks 60(7):52.

Newman, S.E. and J.S. Tant. 1995. Rootzone medium influences growth of poinsettias treated with paclobutrazol-impregnated spikes and drenches. HortScience 30:14031405.

Niu, G., R. Heins, and W. Carlson. 2002. Using paclobutrazol to control height of poinsettia 'Freedom'. Hort Technology 12: 232-236.

U.S. Department of Agriculture. 2009. Floriculture crops 2008 summary. 22 Mar. 2010. <http://usda.mannlib.cornell. edu/usda/current/FlorCrop/FlorCrop04-23-2009.pdf>.

Wilfret, G.J. 1978. Height regulation of poinsettia with a growth regulator incorporated into the soil medium. Proc. Florida State Hort. Soc. 91:220-222.

Wilfret, G.J. 1993. Comparative effect of growth regulators on poinsettia. Proc. Florida State Hort. Soc. 106:294-297.

Wilfret, G.J. 1996. Response of seventeen poinsettia cultivars to growth regulators. Proc. Florida State Hort. Soc. 109:5-7. 